Note

\title{
NATURAL CROSSINGAND ISOLATION DISTANCE BETWEEN COTTON GENOTYPES IN TURKEY
}

\author{
Taner Bozbek ${ }^{1}$; Nedim Ozbek ${ }^{1}$; Volkan Sezener ${ }^{1}$; Oktay Erdogan ${ }^{1}$; Ilkay Yavas²; Aydin \\ Unay $^{2 *}$ \\ ${ }^{1}$ Nazilli Cotton Research Institute - Aydin - Turkey. \\ ${ }^{2}$ Adnan Menderes University/ Faculty of Agriculture - Dept. of Crop Science - 09100 - Aydin -Turkey. \\ *Corresponding author < aunay@adu.edu.tr>
}

\begin{abstract}
The purposes of this study were to determine the percentage of out-crossing, isolation distance and pollinator insect species for cotton (Gossypium hirsutum L.) seed production in the Aydin region in Turkey. The glandless and red-leaf traits in G. hirsutum were used as genetic markers. Two experiments were conducted over two years that monitored out-crossing in adjacent rows and adjacent plants and established that the percentage of out-crossing varied. The percentage of out-crossing varied between $0 \%$ and $13.3 \%$ depending on the genetic marker. In the experiment to determine isolation distance, natural crossing percentage was not observed in 2002, while this percentage was $0.8 \%$ in the first rows in 2003. In this study, cotton fields were also visited once a week during flowering periods for seven weeks in order to determine the numbers of pollinator insect species, where the only detected species was the honey bee. The numbers of pollinator insects were $2.14 \%$ (2002) and $1.30 \%$ (2003) for adjacent rows; $1.71 \%$ (2002) and 2.00\% (2003) for adjacent plants in glandless parcels. It is recommended that the isolation distance between genotypes should be approximately $1 \mathrm{~m}$.
\end{abstract}

Key words: glandless, read-leaf, out-crossing, pollinator insect, seed purity

\section{CRUZAMENTO NATURALE DISTÂNCIADE ISOLAMENTO ENTRE GENÓTIPOS DEALGODÃO NATURQUIA}

\begin{abstract}
RESUMO: Os objetivos deste estudo foram determinar a percentagem de cruzamentos livres, a distância de isolamento e as espécies de insetos polinizadores na produção de sementes de algodão (Gossypium hirsutum L.) na região de Aydin, na Turquia. Foram utilizadas as características ausência de glândulas e folhas vermelhas como marcadores de G. hirsutum. Dois experimentos foram conduzidos durante dois anos, nos quais os cruzamentos livres em linhas e plantas adjacentes foram monitorados, tendo sido comprovada uma variação na percentagem de cruzamentos livres que variou entre 0 e 13,3\% dependendo do marcador genético. No experimento de determinação da distância de isolamento, não se observou cruzamento natural em 2002, mas em 2003 sua percentagem foi de 0,8\%, apenas nas primeiras linhas. Neste estudo, os campos de algodão foram visitados uma vez por semana, por sete semanas, para determinar o número de espécies de insetos polinizadores, tendo sido encontradas abelhas produtoras de mel. O número encontrado foi de 2,14\% (2002) e 1,30\% (2003) para linhas adjacentes; $1,71 \%$ (2002) e 2,00\% (2003) para plantas em parcelas com ausência de glândulas. É recomendado que a distância de isolamento entre genótipos deva ser de aproximadamente $1 \mathrm{~m}$.

Palavras-chave: sem glande, folhas vermelhas, cruzamentos livres, inseto polinizador, pureza de semente
\end{abstract}

\section{INTRODUCTION}

Cotton (Gossypium hirsutum L.) lint production in the Aegean Region for the 2005/2006 season was $254,000 \mathrm{t}$ in 176,000 ha and the lint yield was $1,445 \mathrm{~kg} \mathrm{ha}^{-1}$ (Ozudogru \& Cakaryildirim, 2005). The Aydin province has 47,695 ha of cotton planting areas and 190,123 $\mathrm{t}$ for cotton seed production. Cotton seed is produced by the government and private organizations in the cotton planting areas of Turkey. The isolation distance between different cotton varieties for Certified, Foundation and Registered cotton seed production are a very important requirement to achieve the seed purity standards for various markets (Thomas et al., 2001).

Isolation distance is affected by natural outcrossing in cotton. Temperature, relative humidity, pollinator insects (Oglakci et al., 2000) and materials as genetic markers such as red-leaf and glandless traits have effects on the percentage of outcrossing in cotton. The species, population, activity and also fly pattern of the insect pollinators may in- 
fluence the percentage of natural cotton out-crossing (Xanthopoulos \& Kechagia, 2000).

Generally, G. hirsutum genotypes, glandless trait $\left(\mathrm{gl}_{2} \mathrm{gl}_{2}, \mathrm{gl}_{3} \mathrm{gl}_{3}\right)$ and red-leaf trait $\left(\mathrm{R}_{1} \mathrm{R}_{1}\right)$ are used as markers to determine the percentage of cross pollination in cotton. Oglakci et al. (1996) harvested all acceptor and non-replicate materials and found that the percentage of natural out-crossing was 1.8\% in alternating plants, $0.7 \%$ in alternating rows using red plants, and $2.51 \%$ using glandless plants. This percentage ranged from $0.5 \%-1.4 \%$ in the study of Nadagoudar et al. (1985).

There were also many studies on natural outcrossing in different cotton production areas of Turkey. The percentage of natural cotton outcrossing was 2.0 - 3.0\% for the Antalya Region (Unay et al., 1998), 0.87 - 2.51\% for Harran (Yolcu, 1995), $0.11-0.78 \%$ for Hatay (Mert \& Bayraktar, 1993) and 8.5 - 13.3\% for Kahramanmaras (Oglakci et al., 2000).

The present study determines the extent of natural cotton out-crossing in Aydin, which will be used to develop isolation recommendations for cottonseed production.

\section{MATERIALAND METHODS}

The studies were conducted in Aydin, located in West Turkey, and the region has a typical Mediterranean climatic condition $\left(37^{\circ} 44^{\prime}-37^{\circ} 49^{\prime} \mathrm{N}, 27^{\circ} 44^{\prime}\right.$ $27^{\circ} 50 \mathrm{E}$ ), during 2002/2003. The G. hirsutum genotypes, Nazilli 84 S (Aegean Region standard cotton variety), Glandless Nazilli and McNamara (red-leaf), were the materials used for this study. Two experiments were conducted: Experiment 1, glandless trait $\left(\mathrm{gl}_{2} \mathrm{gl}_{2}, \mathrm{gl}_{3} \mathrm{gl}_{3}\right)$ and red-leaf trait $\left(R_{1} R_{1}\right)$ were used to measure the percentage of cross pollination. The glandless Nazilli (acceptor) and Nazilli $84 \mathrm{~S}$ (donor), and McNamara (donor) and Nazilli $84 \mathrm{~S}$ (acceptor) were sown according to the sowing design of alternating rows and alternating plants in a row. There were ten rows in each plot, each row was $12 \mathrm{~m}$ long, and the row-spacing was 0.7 $\mathrm{m}$. All seed cotton material of glandless Nazilli and Nazilli $84 \mathrm{~S}$ were harvested, and ginned. All seeds of glandless Nazilli and Nazilli $84 \mathrm{~S}$ were sown after the number of glanded $F_{1}$ plants and red-leaf $F_{1}$ plants were counted. The percentages of out-crossing were expressed as the percentage of glanded and red-leaf plants as a proportion of total plants sown; Experiment 2, carried out in order to determine the isolation distance, redleaf genotype (McNamara) was sown in eight rows 0.7 $\mathrm{m}$ spacing, $5.0 \mathrm{~m}$ long. This area was surrounded from all sites by the green-leaf genotype, Nazilli $84 \mathrm{~S}$ in eight rows with $0.7 \mathrm{~m}$ spacing and $5.0 \mathrm{~m}$ long (Figure 1).

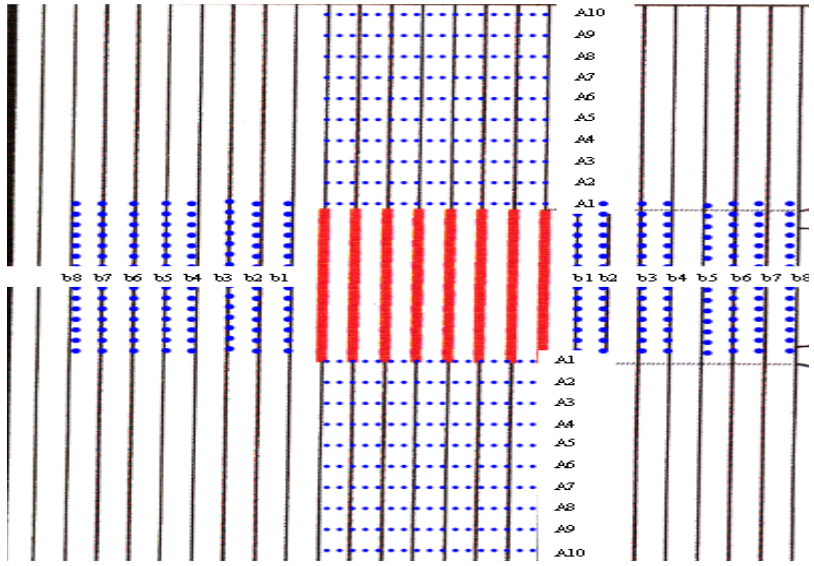

Figure 1 - Layout of the experimental design.

This study was conducted using a randomized complete block design with four replications. In the design, rows planted in the same direction with Mc Namara were called "a" rows and rows planted parallel to Mc Namara were called "b" rows (Figure 1). At harvest boll samples were taken at the bottom, middle and top of all plants in each row of Nazilli $84 \mathrm{~S}$. Sampled bolls from each plant were bulked for each row and separately ginned. Germination tests were replicated ten times with 100 seeds and the number of red color seedlings was counted and recorded for each row.

Cotton flowers were observed once a week during flowering periods for seven weeks in order to determine the number of pollinator insect species. Twenty-five flowers of Nazilli $84 \mathrm{~S}$ and 25 flowers of McNamara in adjacent rows; 25 flowers of Nazilli $84 \mathrm{~S}$ and 25 flowers of Glandless Nazilli in adjacent plants were screened. A similar method was applied to study the isolation distance in relation to parcels. Insects found on the flowers were identified by the Plant Protection Section of Nazilli Cotton Research Institute.

\section{RESULTS AND DISCUSSION}

Percentages of cross pollination were $0.5 \%$ $1.7 \%$ for adjacent rows in Nazilli $84 \mathrm{~S}$-Mc Namara parcels, while these rates varied between $13.0 \%$ and 13.3\% for Glandless Nazilli - Nazilli 84 S (Table 1). The cross pollination rate varied from $0 \%-0.3 \%$ for adjacent plants in Nazilli $84 \mathrm{~S}$-Mc Namara parcels, whereas this range was $8.1 \%-8.9 \%$ for Glandless Nazilli - Nazilli 84 S.

The difference between the two materials (McNamara and Glandless) was considerable. Similarly, Gurel (1984) and Unay et al. (1998) have shown that the percentage of cross pollination for glandless ma- 
terial was higher than that of other materials. The differences between McNamara and Glandless materials can be a result of the insect-attractive effect of the glandless trait in cotton. On the other hand, nowadays, the percentage of cross pollination between $13.0 \%$ and $13.3 \%$ does not reflect the real natural cotton outcrossing or the problem of cotton seed purity, because all commercial cultivars in cotton growing areas of Turkey are glanded cotton varieties. Red-leaf and glandless cotton varieties were only used in the study as materials to determine the percentage of natural crossing.

The only pollinator insect species was the honey bee (Aphis mellifera Hym. Aphidae). The number of honey bees observed in each week during 2002 - 2003 is given in Table 2. Numerous types of bees, including Melissodes species, honey bees (A. mellifera), and bumblebees (Bombus spp.) have been mentioned in multiple studies as the primary pollinators of upland varieties (Moffet et al. 1980, 1978;
McGregor et al., 1976). By comparison, honey bees have been described as secondary pollinators (Waller et al., 1985; Waller, 1972).

The numbers of pollinator insects is shown in Table 2. These numbers were $2.1 \%$ (2002) and $1.3 \%$ (2003) for adjacent rows; $1.7 \%$ (2002) and 2.0\% (2003) for adjacent plants in glandless parcels. In cotton growing areas of Turkey, heavy use of insecticides (especially for the spider mite) and other pesticides may have caused a decrease in the number of pollen vectors.

In the experiment to determine isolation distance, the natural crossing percentage was not observed in 2002, while this percentage was $0.8 \%$ in the first rows for 2003, and statistical analysis was not performed. The number of pollinator insects for isolation distance ranged from $0.9 \%$ to $1.9 \%$ in 2002 2003 (Table 3). Xanthopoulos \& Kechagia (2000) found that out-crossings for 2, 10 and $15 \mathrm{~m}$ distance were $2.8 \%, 0.3 \%$ and $0.1 \%$, respectively. Sen and

Table 1 - Cross-pollination rates for 2002 and 2003.

\begin{tabular}{lcc}
\hline \multirow{2}{*}{ Traits } & \multicolumn{2}{c}{ Cross-pollination rates $(\%)$} \\
\cline { 2 - 3 } & 2002 & 2003 \\
\hline Adjacent Rows (Nazilli 84 S -Mc Namara) & 0.52 & 1.70 \\
Adjacent Plants (Nazilli 84 S -Mc Namara) & 0.00 & 0.30 \\
Adjacent Rows (Glandless Nazilli - Nazilli 84 S ) & 12.97 & 13.30 \\
Adjacent Plants (Glandless Nazilli - Nazilli 84 S) & 8.93 & 8.10 \\
\hline
\end{tabular}

Table 2 - The number of pollinator insects (honey bees) for 2002-2003.

\begin{tabular}{|c|c|c|c|c|c|c|c|c|c|}
\hline \multirow{3}{*}{$\begin{array}{l}2002 \\
\text { Adjacent Rows }\end{array}$} & \multicolumn{9}{|c|}{ The number of pollinator insect (per 25 flowers) } \\
\hline & \multicolumn{9}{|c|}{ Week } \\
\hline & 1. & 2. & 3. & 4. & 5. & 6. & 7. & Total & Average \\
\hline Nazilli $84 \mathrm{~S} / \mathrm{Mc}$ Namara & 0 & 1 & 1 & 2 & 1 & 1 & 1 & 7 & 1.00 \\
\hline \multirow[t]{2}{*}{ Nazilli $84 \mathrm{~S}$ / Glandless } & 1 & 2 & 4 & 3 & 2 & 2 & 1 & 15 & 2.14 \\
\hline & \multicolumn{9}{|c|}{ The number of pollinator insect (per 25 flowers) } \\
\hline \multirow[t]{2}{*}{ Adjacent Plants } & \multicolumn{9}{|c|}{ Week } \\
\hline & 1. & 2. & 3. & 4. & 5. & 6. & 7. & Total & Average \\
\hline Nazilli $84 \mathrm{~S} / \mathrm{Mc}$ Namara & 1 & 0 & 1 & 1 & 0 & 1 & 1 & 5 & 0.71 \\
\hline Nazilli $84 \mathrm{~S} /$ Glandless & 2 & 2 & 3 & 2 & 1 & 2 & 0 & 12 & 1.71 \\
\hline 2003 & \multicolumn{9}{|c|}{ The number of pollinator insect (per 25 flowers) } \\
\hline \multirow[t]{5}{*}{ Adjacent Rows } & \multicolumn{9}{|c|}{ Week } \\
\hline & 1. & 2. & 3. & 4. & 5. & 6. & 7. & Total & Average \\
\hline & 2 & 2 & 4 & 2 & 2 & 1 & 1 & 14 & 2.00 \\
\hline & 1 & 1 & 2 & 3 & 2 & 0 & 0 & 9 & 1.30 \\
\hline & \multicolumn{9}{|c|}{ The number of pollinator insect (per 25 flowers) } \\
\hline \multirow[t]{2}{*}{ Adjacent Plants } & \multicolumn{9}{|c|}{ Week } \\
\hline & 1. & 2. & 3. & 4. & 5. & 6. & 7. & Total & Average \\
\hline Nazilli 84 S / Mc Namara & 3 & 2 & 2 & 2 & 3 & 1 & 1 & 14 & 2.00 \\
\hline Nazilli 84 S / Glandless & 2 & 1 & 5 & 2 & 3 & 0 & 1 & 14 & 2.00 \\
\hline
\end{tabular}


Table 3 - The number of pollinator insect for isolation distance in 2002-2003.

\begin{tabular}{|c|c|c|c|c|c|c|c|c|c|}
\hline \multirow{3}{*}{2002} & \multicolumn{9}{|c|}{ The number of pollinator insect (per 25 flowers) } \\
\hline & \multicolumn{9}{|c|}{ Week } \\
\hline & 1. & 2. & 3. & 4. & 5. & 6. & 7. & Total & Average \\
\hline Mc Namara & 3 & 1 & 3 & 3 & 0 & 2 & 1 & 13 & 1.86 \\
\hline Nazilli $84 \mathrm{~S}$ & 2 & 0 & 2 & 1 & 1 & 1 & 1 & 8 & 0.88 \\
\hline \multirow[t]{3}{*}{2003} & \multicolumn{9}{|c|}{ The number of pollinator insect (per 25 flowers) } \\
\hline & \multicolumn{9}{|c|}{ Week } \\
\hline & 1. & 2. & 3. & 4. & 5. & 6. & 7. & Total & Average \\
\hline Mc Namara & 3 & 1 & 2 & 3 & 1 & 2 & 1 & 13 & 1.86 \\
\hline Nazilli $84 \mathrm{~S}$ & 2 & 1 & 2 & 2 & 1 & 1 & 1 & 10 & 1.42 \\
\hline
\end{tabular}

Cicek (2003) reported similar results. Both researches revealed that distances $>10 \mathrm{~m}$ between cotton plants can effectively prevent natural crossing. In Turkey, methods and rules published by the International Union for the Protection of New Varieties of Plants (UPOV) have been used, and the isolation distances are $200 \mathrm{~m}$ for breeder seeds and basic seeds, $100 \mathrm{~m}$ registered seeds and $50 \mathrm{~m}$ certified seeds.

\section{CONCLUSIONS}

The highest natural crossing ratio observed for cotton was $1.7 \%$ for glanded cotton cultivars. Since all cotton cultivars grown in Turkey are glanded, isolation distance should be less than $10 \mathrm{~m}$ for cotton seed production.

\section{REFERENCES}

McGREGOR, S.E. Insect pollination of cultivated crop plants. Agriculture Washington, D.C.: U.S. Government Printing Office, 1976. 411p. (Handbook, 496).

MERT, M.; BAYRAKTAR, N. A research on the determination of cross pollination ratio in cotton (Gossypium hirsutum L.) under Amik plain conditions. In: NATIONAL FIELD CROPS CONGRESS, 1., Izmir, 1994. Proceedings. Ízmir: Aegean University, Agr. Fac. Press, 1993. v.2, p.227-230.

MOFFET, J.O.; SHIPMAN, C.W. Producing hybrid cotton seed on a field scale by using honeybees as pollinators. In: BELTWIDE COTTON PRODUCTION RESEARCH CONFERENCE, Dallas, 1978. Proceedings. Memphis: National Cotton Council of America, 1978. p.77-80.

MOFFET, J.O.; COBB, H.B.; RUMMEN, D.R. Bees as potential value as pollinators in the production of hybrid cotton seed on the High Plains of Texas. In: BELTWIDE COTTON PRODUCTION RESEARCH CONFERENCE, Memphis, 1980. Proceedings. Memphis: National Cotton Council of América, 1980. p.268-270.

NADAGOUDAR, B.S.; JOSHI, V.R.; VE KATARKI, B.H. Isolation distance in cotton seed production. Cotton Development, v.15, p.7-9, 1985.
OGLAKCI, M.; EFE, L.; CIÇEK, B.; CIRA, A.A. Research on the determination of natural crossing percentage of cotton (Gossypium hirsutum L.) in K. Maras conditions. In: THE INTER-REGIONAL COOPERATIVE RESEARCH NETWORK ON COTTON, Adana, 2000. Adana: Cukurova University Press, 2001. p.33-35, 2000.

OGLAKCI, M.; S. YOLCU, S.; YUCEL, A. A research on the Percentage of Natural Cross pollination in cotton (Gossypium hirsutum L.) and pollinators in Harran Region conditions. In: JOINT MEETING OF WORKING GROUPS, COTTON BREEDING, COTTON VARIETY TRIALS, Adana, 1995. Proceedings. Adana: Cukurova University Press, 1996. p.5052.

OZUDOGRU, T.; CAKARYILDIRIM, N. Cotton situation and outlook: 2005/2006. Ankara: Agricultural Economics Research Institute, 2005. 40p.

SEN, I.; CICEK, B. The determination of natural cotton cross pollination, isolation distance and pollinator insect species under Kahramanmaras conditions. K.Maras: Agricultural Research Institute Publications, 2003. 13p.

THOMAS, B.R.; BRADFORD, K.; SUNDSTROM, C. Pollen transfer in cotton seed production. 2001. Available at http:// danrrec.ucdavis.edu/shafter/field_day/01-02/15_thomas.pdf. Accessed 12 Oct. 2003.

UNAY, A.; KAYNAK, M.A.; GÜREL A.; AKDEMIR H.; SERTER E. The extent of cross pollination for seed production in cotton. In: AGRICULTURAL CONGRESS OF AEGEAN REGION, 1., Aydin, 1998. Ankara: TC Agr. Bank Press, 1998. p.197-202

WALLER, G.D. Evaluating responses of honey bees to sugar solutions using an artificial flower feeder. Annals of the Entomological Society of America, v.65, p.852-861, 1972.

WALLER, G.D.; MOFFET, J.O.; LOPER, G.M.; MARTIN, J.H. Evaluation of honey bees foraging activity and pollination efficacy for male-sterile cotton. Crop Science, v. 215, p.211214, 1985.

XANTHOPOULOS, F.P.; KECHAGIA, U.E. Natural crossing in cotton. In: THE INTER-REGIONAL COOPERATIVE RESEARCH NETWORK ON COTTON, Adana, 2000. Adana: Cukurova University Press, 2001. p.27-32.

YOLCU, S. The determination of natural cotton pollination percentage and pollinator insect species under Harran Plain Conditions of Turkey. Harran: University of Harran, 1995. 24p. Master Thesis

Received October 31, 2006

Accepted September 18, 2007 